\title{
Hvorfor er Afrika så fattigt?
}

Greg Mills

Hovedårsagen til Afrikas fattigdom er, at de fleste af kontinentets lande har ledere, der favoriserer egne eliter til skade for befolkningerne. I andre dele af verden ses forhindringer for udvikling som noget, der skal overvindes. I Afrika som evige undskyldninger for mangel på succes

Med en pro capita indkomst 50 procent mindre end verdens næstfattigste region, Sydasien, er væksten i Afrika syd for Sahara haltet bagefter siden uafhængigheden for 50 år siden.

Der er fremført mange grunde til regionens langsomme udvikling: manglen på borger- og regeringskapacitet, ringe infrastruktur, ringe tilgang til handel, for lidt (eller for meget) hjælp udefra, arven efter arbitrære koloniale grænser, lav produktivitet, den kolde krig, klimaet og geografi.

Fra de fleste afrikanske regeringers side er svaret på spørgsmålet 'Hvorfor er Afrika så fattigt?', at det skyldes den øvrige verden, og at løsninger derfor er uden for deres rækkevidde.

Men verden har ikke nægtet Afri- ka markeder eller finansielle midler til at konkurrere, og den moderne æras globalisering har givet hidtil usete muligheder på opgående markeder. De har nok haft vanskeligheder for nylig, men den globale rigdom er tredoblet siden 1990. Det er imidlertid regeringers varierende evner for at omdanne disse muligheder til udvikling og velstand, der i vidt omfang ligger bag øgede uligheder inden for og imellem lande.

Det har ikke per se været på grund af hjælpen, selv om den tese på det seneste har fået øget vægt. Afrikas fattigdom er heller ikke alene konsekvensen af ringe afrikansk infrastruktur eller ringe handelsadgang. Afrika har haft privilegeret adgang til internationale markeder, men er alligevel fortsat med at glide bagud på grund af overdreven af- 
hængighed af primært råvareeksport.

Mens meget af Afrikas infrastruktur er forværret og faldet bagud i forhold til andre dele af verden, har det ikke altid været tilfældet. Og i virkeligheden har der ofte været stærke personlige interesser $i$ at fastholde det sådan.

Det er meget sigende, at mange afrikanske lande har undladt at etablere politikker og procedurer til at lette handel. Det kunne være gjort hurtigere og meget billigere end forbedring af infrastruktur.

\section{Slipper af sted med det}

Afrikas fattigdom skyldes ikke, at den nødvendige udvikling og tekniske ekspertise mangler internationalt. Den kan købes på det internationale marked, som mange i Asien har valgt at gøre. Den kunne endog fås gratis fra donorer.

Men Afrika har vist en særlig stærk besiddertrang med hensyn til retningen for og kontrollen med kontinentets udvikling, delvis på grund af et dybtliggende skeptisk syn på folk udefra, men også fordi det er sluppet af sted med at optræde sådan.

Afrika er ikke fattigt, fordi afrikanere ikke arbejder hårdt. Deres produktivitet er lav af forskellige grunde, herunder dårligt helbred og uddannelse samt ineffektiv udnyttelse af jord og chauvinisme. Men kun få om nogen kan hævde at arbejde så hårdt (og for mindre udbytte) end afrikanske kvinder i landområderne.

Afrika er heller ikke fattigt på grund af manglen på naturressourcer. I sammenligning med Asien er det et utroligt skatkammer, når det for eksempel gælder vandkraft. Men med få undtagelser (Botswana er en af dem) er disse ressourcer kun brugt til at berige eliterne, sprede korruption og aflede opmærksomheden og energien fra udvikling.

$\mathrm{Og}$ afrikanerne er ikke ramt af fattigdom, fordi der ikke eksisterer en privat sektor, eller fordi at den har været uvillig til at arbejde under vanskelige vilkår. Men den private sektor er ofte slet ikke 'privat', men snarere en form for leasing, som er knyttet til eliter. Selv hvor der er en grad af uafhængighed, er regeringers holdning til privat business styret af mistænksomhed eller direkte fjendtlighed.

\section{Fattigdom som et valg}

Hovedårsagen til, at afrikanerne er fattige, er, at deres ledere har truffet det valg.

Erfaringerne viser, at lande kan få deres $\varnothing$ konomier til at vokse og udvikles, hvis lederne træffer sunde beslutninger, der er i national interesser. Det er lige så sandt for Vietnam før og efter reformers fallit, som det er for afrikanske reformatorer fra Ghana til Botswana. Afrikas positive økonomiske vækst i 0'erne viser, at der kan træffes bedre valg. 
Succes i den globale økonomi har heller ikke krævet et mirakel eller en særlig eliksir. Når man giver afrikanske ledere skylden for ikke at have grebet mulighederne, må det også erkendes, at de ofte har truffet beslutninger under særligt vanskelige vilkår. Ingen benægter, at lederne står over for store udfordringer i Afrika. Men i andre dele af verden ses de som regel som forhindringer, der skal overvindes, ikke som permanente undskyldninger for fallit som i Afrika.

Afrika har ikke udnyttet sine potentialer i det halve århundrede med uafhængighed. I stedet har dets største naturlige aktiv undergravet dets velstand. Afrikas unge opfattes ikke som en enorm kilde af talent og energi, som må udnyttes, men som en destabiliserende kraft, fordi så mange af dem er arbejdsløse og uden uddannelse. Det er ikke kun en trussel imod Afrikas sikkerhed. I 2025 vil hver fjerde unge i verden komme fra Afrika syd for Sahara. De fleste vil bo i afrikanske byer, hvor flertallet af kontinentets borgere vil befinde sig på det tidspunkt. Og hvis de ikke finder arbejde på kontinentet, vil de søge andre steder hen.

\section{Olierigdommene}

Afrikas olierigdomme har ikke været en kilde til udvikling, kun til at berige eliterne. For eksempel Nigeria: Anslået 400 milliarder dollar i olie- indtægter over 40 år sikrede, at olieindtægten per capita steg fra 33 USD til 325 USD fra 1965 til 2000, men antallet af nigerianere, der lever for mindre end en dollar om dagen, steg fra 19 millioner i 1970 (ud af en befolkning på dengang 70 millioner) til 90 millioner (ud af 120 millioner plus).

I stedet for at være brændstof til udvikling har olien fordærvet regeringer og svækket deres ansvarlighed på tværs af Afrika.

Og i stedet for at være spisekammer for verden er Afrikas landbrugspotentiale på samme måde ødslet bort. Selv om mange afrikanske lande havde naturlige fordele, var 35 af de 48 økonomier syd for Sahara nettoimportører af fødevarer i slutningen af 0'erne. Afrikas andel af verdens eksport af landbrugsvarer er halveret siden 1970 til under fire procent.

Selv om landbrug kun udgjorde en femtedel af kontinentets økono$\mathrm{mi}$, var to tredjedele af afrikanerne i slutningen af 0 'erne afhængige af landbrug for at overleve - det store flertal af dem kvinder. Der skal ikke et geni til at regne ud hvorfor. Der er hverken investeret nok tid, anstrengelser eller penge i forbedring af afgrøder. Det har ikke været prioriteret af afrikanske regeringer. $\mathrm{Og}$ i stedet for industrialisering og diversificering af deres økonomier, er afrikanske lande forblevet afhængige af eksport af basale produkter og af globale råstofpriser. 
Hvis Afrikas elendige økonomiske performance kan begrundes i afrikanske lederes dårlige valg, må vi spørge: Hvorfor har de truffet de valg?

En nøgleårsag er, at afrikanerne og det internationale samfund har givet dem lov til det. Afrikanerne har typisk troet, at lederne manglede midlerne til at ændre status quo, mens det internationale samfund har været for parat til at hjælpe dem af grunde, der spænder fra egeninteresser til altruisme og medlidenhed.

Afrikanske ledere har med hjælp fra donorer haft succes med at eksternalisere problemerne og gøre dem til andres ansvar (og angiveligt også skyld). Over for det har donorer manglet redskaber eller politisk vilje til at styre relationerne og pengestrømmene i overensstemmelse med modtagernes evne til at levere demokrati og reformer.

Ikke nogen andre steder i verden har man set så mange såkaldt 'skrøbelige' eller 'fejlslagne' stater, der har overladt ansvaret for at finde ressourcerne til at genopbygge deres lande til andre, ofte overflødige autoriteter. Alt for ofte er donorer, bevidst eller ikke, trådt i staternes sted og dermed har de svækket de allerede spinkle bånd af ansvarlighed mellem regeringer og deres befolkninger.

At afrikanske ledere fik lov til at slippe af sted med ødelæggende, egoistiske beslutninger kan i vidt omfang tilskrives kontinentets relati- ve mangel på demokrati (eller eksistensen af etpartistyre). Der har været ringe pres nedefra på lederne til at træffe bedre valg på trods af vækst i det civile samfund i de dele af kontinentet i det seneste årti.

\section{Korruption og nepotisme}

Den tilsyneladende folkelige passivitet over for jammerligt lederskab kan i hvert fald delvist tilskrives kultur: forkærlighed for neo-patriarkalske 'stærke mænd' og høvdingeagtige ledere, der tildeler privilegier og bruger alle midler til at styrke deres herredømme, fra traditionelle regeringsstrukturer til slægtskabsbånd og mindre håndgribelige ting som heksekraft og kirken. Og systemet, som mange afrikanske ledere har foretrukket, befordrer korruption og nepotisme.

Men det kulturelle aspekt har fungeret begge veje - et ubehageligt faktum, som de fleste forskere og feltarbejdere ikke har viet nok opmærksomhed. Mens afrikanske ledelser har manglet engagement for folkelig velfærd, som mange asiatiske ledere har vist, har asiatiske folk på deres side påtaget sig ansvar (og dertil svarende mentalitet) for at indfri deres del af udviklingshandlen - det konfucianske aspekt, der ofte fremhæves, men er så svært at kvantificere i Østasiens succes.

Afrikas relativt lave befolkningstæthed har også spillet en rolle. Afrika har historisk manglet en kritisk 
masse af faglærte til at deltage i udviklingen, især i byerne. Og det har resulteret i høje arbejdsomkostninger og lav økonomisk vækst.

Afrikas jordejerstruktur har også været en forhindring for iværksætteraktivitet, da den har hæmmet forøgelse af jordværdien igennem individuelt ejerskab og belåningsmuligheder. Der har også her været ringe interesse i reformer blandt lederne i mange lande. I Zimbabwe er jorden tværtimod beslaglagt og redistribueret efter politisk tilhørsforhold.

Kolonimagternes skabelse af stater og grænser oppefra og ned i Afrikas rige etniske og sekteriske landskab institutionaliserede svage regeringsstrukturer. De blev både dannet og opretholdt ikke ved at hæve skatter og sikre offentlige goder, som under europæiske statsdannelser, men gennem internationale diktater fra kolonimagter over Organisationen for Afrikansk Enhed (OAV) til nutidens offentlige alliancer med donorer, som har sikret hovedparten af mange afrikanske regeringers udgifter. Endelig og måske allervigtigst er der truffet dårlige valg, fordi bedre valg til fordel for almene offentlige interesser i mange tilfælde var i strid med lederens personlige og/eller finansielle interesser.

\section{Donorernes darling}

Zambia er et eksempel på et land, der har lidt under denne politiske syge, samtidig med at der næppe er noget andet land, som er blevet studeret så intensivt af udviklingsrådgivere som netop Zambia.

Det har været en darling for donorer siden uafhængigheden i 1964. Et utal af rapporter er skrevet af Verdensbanken og andre om ethvert tænkeligt emne i landet - fra transport, til turisme, over tilsynsreformer til mindedrift. Så det er ikke, fordi zambianere ikke ved, hvad der skal gøres, når det gælder udviklingsproblemer. I næsten et halvt århundrede har de debatteret, hvordan økonomien diversificeres væk fra minedrift til landbrug, turisme og produktion. Endnu med sparsomme resultater.

De fleste af de rapporter er endt på støvede regeringshylder, og deres ofte gentagne forslag er sjældent læst eller praktisk taget aldrig fulgt op med handling.

Zambias økonomi har imidlertid klaret sig godt i 0'erne. Privatisering af landets hovedeksportkilde, kobberminerne, har resulteret i fire milliarder dollar i interne investeringer. Den årlige kobberproduktion er tredoblet på 15 år og er nu næsten tilbage til dens tidligere størrelse på 720.000 ton. $\varnothing$ konomien er vokset med over fem procent. Lusakas tætte trafik illustrerer den øgede levestandard og opkomsten af en middelklasse i den centralafrikanske stat.

Men landet burde kunne gøre det meget bedre. Den høje arbejdsløs- 
hed, især blandt de unge, er ingen opskrift på langsigtet stabilitet. "Arbejdsløshedshærens omfang vil en dag gøre Zambia ude af stand til at overleve", siger Hakainde Hichilema, bedre kendt som 'HH', en ledende oppositionsfigur.

Zambias infrastruktur er på sammenbruddets rand og dyr for business. Det tager en uge at få eksport ud via landevej til Sydafrika og fire gange så lang tid med tog. Energimangel truer, selv om landet er velsignet med overdådige vandenergipotentialer. Minesektoren er underudviklet i sammenligning med andre kobberproducenter som fx Chile. Turismen forbliver presset sammen omkring Victoria Falls, trods de ekstraordinære tilbud andre steder, fra Lower Zambezi til Tanganyika Søen.

Landet har på ingen måde levet op til sine betragtelige potentialer, og regeringen har ikke travlt med at iværksætte sunde planer for indfrielse af nationens behov. I stedet har den undertiden gjort det sværere for sig selv med uigennemtænkte skatter på jord og minedrift, der truede med at tvinge producenter i begge sektorer ud i fallit, før regeringen foretog et tilbagetog.

Men hvorfor dog den søvngængerpolitik?

Regeringen siger, at den er begrænset af politik og må bevæge sig langsomt med reformer, da den ellers risikerer at fremstå som reaktionær. Den siger, at demokrati i sig selv har gjort de økonomiske muligheder dårlige og kortsigtede på grund af flaskehalse og mangel på kapital.

Andre peger på den skadelige effekt af hjælp, der dækker en tredjedel af regeringens udgifter. Det øger risikoen for politisk inerti at vide, at der er donorer til at samle stumperne op. Og det fjerner incitamenterne til at ekspandere den produktive sektor og skattegrundlaget.

Andre igen peger på dybereliggende årsager, som dog ligeledes er grundlæggende politiske og kulturelle. HH siger, at det går tilbage til, at landet blev styret i 27 år frem til 1991 af den socialistisk sindede Kenneth Kaunda. I hans tid blev staten den største arbejdsgiver og alle forholds regulator med korruption som resultat.

\section{Gearet til protektionisme}

Det har skabt en administration, der er gearet til protektionisme og regulering for enhver pris, og en privat sektor, der er tunet til at arbejde inden for et system, der begunstiger insidere og modarbejder uafhængige initiativer og foretagsomhed. Det skal ikke undervurderes, hvor fint det system arbejder for eliten - et karaktertræk for de fleste afrikanske lande.

Men tiden er nu gunstig for afrikanske ledere til at fremme diversificering af deres økonomier. Råvarepriserne er høje, og det åbner i sig 
selv for en række politiske valg. Investorer har appetit for opstigende markeder med stor vækst. Og mange af de barske makroøkonomiske reformer er gennemført på tværs af kontinentet.

Men for at nå det næste niveau må Afrika gennemføre omfattende reformer i de eksisterende regelsæt. Det burde fx ikke kræve 33 forskellige tilladelser at arbejde i Zambias turistsektor. Troværdige politiske forhold og et attraktivt skatteregime må også til.

\section{Investorer $=$ rovdyr}

Eliterne bør ikke længere sætte politisk magt over økonomisk vækst. De må holde op med at se udenlandske investorer som rovdyr, der frarøver dem deres førstefødselsret. For at klare sig bedre må Afrika signalere, at det er slut med business as usual, hvor politik har forrang for økonomi.

Hermed to eksempler på hvordan Afrika kan klare sig bedre:

Jeg tilbragte en stor del af $2008 \mathrm{i}$ Rwanda som præsidentens strategiske rådgiver. Min families chauffør Frank havde en rigtig god ide til et taxifirma. For at gøre en lang historie kort, kunne han ikke få det finansieret, fordi han ikke var i stand til at udarbejde et forretningskoncept. Resultatet blev, at min partner, Janet, og jeg nu er investorer i et taxifirma i Rwanda. Det var afgørende at skabe et finansielt system, som kunne tage vare på Frank, men det var også svært at skabe efterspørgsel for hans forretning.

Adgangen til det smukke land har været vanskeliggjort af både omkostninger og bureaukrati og der har manglet turistprodukter, bortset fra gorillaer. Mens regeringen retorisk har været åben for besøgende, har den været mindre åben over for investorer, herunder i turistbranchen. Det går til kernen af regeringernes problem med at ønske kontrol med samfundet samtidig med, at stabilitet og vækst i sidste instans kræver liberalisering.

Turisme er en af Afrikas komparative fordele. Den globale turisme er en industri med næsten en milliard besøgende. Men Afrika har kun fire procent af det marked. Mange af udfordringerne med adgang er noget, som kan ændres, herunder liberalisering af flytrafik og visa.

Mit andet eksempel kommer fra forskellige ruteanalyser (foretaget på distancestudier under lastbilture, som vi har foretaget på tværs af kontinentet og andre steder). Vores Afrikaoversigter viser, at en tredjedel af en rejses varighed går med stop ved grænser eller til at bestikke ved politiets eftersyn, en tredjedel til rejse og en tredjedel til at sove, spise etc.

Afrikanere beklager sig ofte over, at infrastrukturen fungerer så dårligt. Men der skal ingen donorpenge til for at holde grænserne åbne 24 timer syv dage om ugen. Dermed 
kunne man få det bedste ud af de eksisterende ressourcer - hvis det altså drejer sig om at forbedre åbenhed og handel.

Eller et andet eksempel. I Singapore tager det gennemsnitligt otte minutter at undersøge hver af de 30 millioner containere, der kommer ind årligt. I Mombasa, den vigtigste østafrikanske indskibningshavn, tager det mindst 72 timer for hver af den halve million containere om året. Meget af forskellen skyldes en kombination af politisk vilje og systemer.

Svaret på 'Hvorfor er Afrika fattig?', ligger således i forskellen mellem succes og fallit i verden som helhed - og afrikanske lande er ikke anderledes på det felt, hvilket fundamentalt set er godt nyt.
Forskellen findes i politiske valg. Og svarene bag valgene ligger fundamentalt set i personligheder og politik. Den vigtigste udfordring for afrikanske økonomer er grundlæggende politisk. For at få succes som i Sydøstasien må Afrika sætte folk og ideer snarere end snæversynet politik i centrum for sin udvikling.

Dr. Greg Mills er leder af Brenthurst Foundation i Johannesburg, der blev etableret $i 2005$ for at styrke Afrikas фkonomiske performance. Hans seneste bog 'Why Africa is Poor - and what Africans can do about it' (Penguin) blev udgivet i oktober 2010.

Denne artikel dannede grundlag for Greg Mills foredrag i DIIS i oktober.

(Oversat fra engelsk af Vibeke Sperling) 